\title{
A STUDY OF INTERACTIONAL METADISCOURSE ON NEWS ARTICLE ON THE IMPACT OF COVID-19 ON EDUCATION
}

\author{
Nur Azyan Aszeli, \\ Daniel Amer Jamil, \\ Noor Hanim Rahmat \\ Akademi Pengajian Bahasa, \\ Universiti Teknologi MARA, \\ Malaysia
}

\begin{abstract}
:
Many different sources and platforms are introduced everyday as information content. News article remains one of the primary forms of textual written sources for the public. Even with the help of metadiscourse in writing, authors still face an issue of misunderstanding and comprehending from their readers. Further analysis is needed to understand the usage of metadiscourse in news article, as it will contribute to comprehending metadiscourse usage. The study aims to analyse metadiscourse on news article about Covid 19 impact on education. The objective of the study is to understand how interactional metadiscourse resources on news articles can be transcribed in terms of hedges and boosters, attitude-markers and engagementmarkers, and Personal Markers. The study is conducted using Hyland (2005) metadiscourse strategies. The researchers decided to use interactional metadiscourse markers to analyse the text as interactional provides a clearer understanding. The study found that the attitude marker is the highest content found in the news article, a percentage of $45.45 \%$. The second highest rate of frequency is hedges and boosters throughout the article. Not only that, the study found that the article contains all interactional markers usage in the text. For future researchers, they should focus on an in-depth analysis on the other side of metadiscourse which is interactive discourse markers and how it can be transcribed.
\end{abstract}

Keywords: news article, interactional markers, attitude markers, hedges and boosters

\section{Introduction}

\subsection{Background of the Study}

Metadiscourse is the commentary on a text made by its producer in the course of speaking or writing and it is a widely used term in current discourse analysis and language teaching (Hyland, 2017). It has been broadly studied in various texts and references such as academic papers,

i Correspondence: email patanim@gmail.com, noorh763@uitm.edu.my 
textbooks, blogs, speech text, and general essays. Metadiscourse is one of the linguistic divisions which explains the direction and purpose of words used in a text. It is often used to lead the reader towards the intent of writing and the course of such concepts presented.

It is one of the definitions of discourse that can be described as the analysis of discourse itself or the aspects of the text that influence the relationship between writers and readers (Chrismore, 1989, as cited in Nordquist, 2018). Hayland in one of the studies described metadiscourse as three-way between the text, the writer, and the reader which permit the writer to deliver messages through text through engagement with the reader (Hyland, 2005, as cited in Tarrayo, 2014).

Text through online news articles can be positive or negatively reviewed by readers depending on the writer's use of language with the consideration of how readers comprehend the meaning. Metadiscourse is, hence, a term of words used by a writer to guide the reader towards the purpose of the writing and the direction of some suggested idea in the text (Abdul Kadir et al. 2020, p. 130).

\subsection{Statement of Problem}

The usage of metadiscourse is present in writing to enhance the expression and feelings of a writer in terms of words (Hyland, 2017). Writers expect their readers to not only understand their writings but also in the shoes of the writer. Metadiscourse is important and contributes to connecting to the readers. It is essential that writers use metadiscourse in their writings so that the writer will be able to convey their message and idea to the public much clearer than intended (Lee and Deakin, 2016).

On the contrary, when metadiscourse is not used properly, the public might not perceive the intended message of the writer. However, the writer is not to blame nor is their language and communication skills. Mistakes of using the wrong metadiscourse leads to confusion when reading the text. Improper metadiscourse usage strategies affect the audience in a negative way that hinders them from the writing (Ho and Li, 2018).

News articles are one of the primary sources of the publics' reading sources. Nonetheless, news articles are still misunderstood and misinterpreted by many readers. By understanding and learning interactional metadiscourse, it provides writers with a solution to their usage of metadiscourse (Abdullah, Rahmat, \& Zawawi, 2020). The readers vary from all aspects of society, indicating that the readers are from different categories. Even with the proper use of metadiscourse in writing, there still remains confusion among readers. To solve the issue, the usage of interactional discourse of metadiscourse in news articles is explored in the study. The news article selected is based on the impact of Covid-19 on education.

\subsection{Objective}

This study is done answer the following questions;

1) How are interactional metadiscourse resources on news articles transcribed in terms of hedges and boosters?

2) How are interactional metadiscourse resources on news articles transcribed in terms of attitude-markers and engagement-markers? 
3) How are interactional metadiscourse resources on news articles transcribed in terms of personal markers?

4) How does the frequency of usage differ across all metadiscourse markers?

\section{Review of Related Literature}

\subsection{News Article}

With the evolution of technology, there are multiple media sources created everyday, but the majority of the public's primary source of information is news articles (Karakaya \& Glazier, 2019). These articles report the news, story and current events (Tanikawa, 2017). The pandemic has even cause issues of education to be seen in a different light (Wahid, Rahmat, Dzuradeen \& Kadir, 2020) and hence there are many articles written about them. News articles refer to the published writing relating to current or recent news. It is very convenient for the readers due to easy access and reliability.

Not only that, news articles can also focus on specific and particular topics. The purpose of news articles is to inform the readers of the global news around them. News articles are usually published in magazines, newsletters, or websites. They can also appear in advertisements. The content of news articles would include a headline, author information, introduction, body text and quotes. Furthermore, the article is supported by visual aids such as photographs, graphs, statistics, interviews. One of the main sources of information, news articles contain informative data and opinions on world issues.

\subsubsection{Issues on the News Article}

When reading news articles, authors expect the audience to comprehend and understand their writings. Hence, metadiscourse is needed in order to analyse and understand the author's work (Hyland, 2017). Metadiscourse contributes to connecting to the readers and it is essential to analyse news article using metadiscourse to fully understand the message in the text. Next, news article might contain wrong usage of metadiscourse which affects readers where they may not perceive the information as intended (Ho and Li, 2018). Analysing news article will contribute to further understanding of proper usage of certain words and acts as a tool to assist writers with their writings.

\subsection{Metadiscourse}

\subsubsection{Metadiscourse}

Metadiscourse refers to how an author is able to convey their message to the readers. It helps to give perspective and a viewpoint for the author. With that, it assists the readers in understanding the authors views (Abdul Kadir et al., 2020). Not only that, metadiscourse also conveys the expression behind an author's text (Lee \& Deakin, 2016). It is able to enhance the expressions and feelings of an author hence is deemed practical and proper in analyzing text and writings.

Analyzing text using metadiscourse will enable the readers to understand the certain usage of words and phrases used by the author. Metadiscourse analysis can be divided into two, which is interactive and interactional metadiscourse markers. For example, certain markers such 
as hedges helps to indicate purpose of the readers. Interactional metadiscourse will be the focus of the study.

\subsubsection{Interactive}

Table 1: Interactive metadiscourse markers

\begin{tabular}{|c|c|c|c|}
\hline Main Category & Sub-Category & Description & Examples \\
\hline \multirow{5}{*}{$\begin{array}{l}\text { Interactive } \\
\text { Resources }\end{array}$} & Transitions & $\begin{array}{l}\text { Express relations between main } \\
\text { clauses }\end{array}$ & In addition, but, thus, and \\
\hline & $\begin{array}{l}\text { Frame } \\
\text { Markers }\end{array}$ & $\begin{array}{l}\text { Refer to discourse acts, sequences } \\
\text { or stages. }\end{array}$ & $\begin{array}{l}\text { Finally, to conclude, my purpose } \\
\text { is }\end{array}$ \\
\hline & $\begin{array}{l}\text { Endophoric } \\
\text { Markers }\end{array}$ & $\begin{array}{l}\text { Refer to information in other } \\
\text { parts of the text }\end{array}$ & $\begin{array}{l}\text { Noted above, see Fig, in section } \\
2\end{array}$ \\
\hline & Evidentials & $\begin{array}{l}\text { Refer to information from other } \\
\text { text }\end{array}$ & According to $X, Z$ states \\
\hline & $\begin{array}{l}\text { Code } \\
\text { glosses }\end{array}$ & Elaborate propositional meaning & $\begin{array}{l}\text { Namely, e.g.,such as, in other } \\
\text { words }\end{array}$ \\
\hline
\end{tabular}

Source: Hyland's (2005).

Interactive resources consist of five different sub-category which are Transitions, Frame Markers, Endophoric Markers, Evidentials, and Code glosses. The functions of interactive resources are to engage and interact with readers. Transitions consist of examples such as in addition, but, and thus. Frame markers refer to sequences or stages. Endophoric markers would refer to certain words such as noted above, see Fig, and in section 2. Evidentials refer to information for other sources. Finally, Code glosses explains propositional meaning. Interactive resource, however, does not identify the interactional elements in writing.

\subsubsection{Interactional}

Table 2: Interactional metadiscourse markers

\begin{tabular}{|l|l|l|l|}
\hline Main Category & Sub-Category & Description & Examples \\
\hline \multirow{5}{*}{$\begin{array}{l}\text { Interactional } \\
\text { Resources }\end{array}$} & Hedges & $\begin{array}{l}\text { Withhold commitment and } \\
\text { open dialogue }\end{array}$ & $\begin{array}{l}\text { might; perhaps; } \\
\text { possible; about }\end{array}$ \\
\cline { 2 - 4 } & Boosters & $\begin{array}{l}\text { Emphasize certainty or } \\
\text { close dialogue }\end{array}$ & $\begin{array}{l}\text { in fact; definitely; } \\
\text { it is clear that }\end{array}$ \\
\cline { 2 - 4 } & $\begin{array}{l}\text { Attitude } \\
\text { Markers }\end{array}$ & $\begin{array}{l}\text { Express writer's attitude } \\
\text { to proposition }\end{array}$ & $\begin{array}{l}\text { unfortunately; } \\
\text { I agree; surprisingly }\end{array}$ \\
\cline { 2 - 4 } & $\begin{array}{l}\text { Personal } \\
\text { Markers }\end{array}$ & Explicit references to author(s) & I; we; my; me; our \\
\cline { 2 - 4 } & $\begin{array}{l}\text { Engagement } \\
\text { markers }\end{array}$ & $\begin{array}{l}\text { Explicitly build relationship } \\
\text { with reader }\end{array}$ & $\begin{array}{l}\text { consider; note; } \\
\text { you can see that }\end{array}$ \\
\hline
\end{tabular}

Source: Hyland's (2005).

Interactional resources consist of five different sub-category which are Hedges, Boosters, Attitude markers, personal markers. This helps to indicate the certain word and phrases that contributes to reader interaction. Hedges and boosters consist of similar functions, such as 
withhold commitment and emphasizes certain. For Attitude markers and Personal markers, the function consist of expressing writer's attitude and references to authors. Finally, engagement markers refer to explicit build relationship with readers.

\subsection{Past Studies on Metadiscourse in news articles}

Abdullah, Rahmat \& Zawawi (2020) conducted a study using interactional metadiscourse to identify the markers between two articles, a Malaysian author and South Korean author's online newspaper article. The researchers state that interactional resources are used in writings as a tool to enhance focus and add elements of interaction. The study used Hyland's (2005) model of metadiscourse and observe the interactional resources. The findings of the study discovered that personal markers were absent in the articles. The usage of hedges, boosters, engagement markers, and attitude markers were present in both articles. The authors from the articles, were informative on the issues and did not include their own personal opinions on the matter. The South Korean author used more interactional metadiscourse when compared to the Malaysian author. The study suggest that the results will contribute to studies on interactional metadiscourse in online newspaper.

Anuarsham, Rahmat \& Khamsah (2020) on the other hand, adopts document analysis of interactional metadiscourse elements in online newspaper article. Only four markers from the metadiscourse were used by the study, did not include Personal markers. This was conducted to identify relationship between writer and reader. The findings of the study shows that engagement markers is the most frequent interactional metadiscourse marker found throughout the article. The research suggest that the employed method can be applied to other genres of online newspaper articles. The study will contribute to metadiscourse framework from academic institutes.

\section{Methodology}

\subsection{Research Design}

Document analysis and textual analysis were carried out for qualitative analysis of the data where the papers written by Bob Spires in the University of Richmond's blog were conscientiously read to identify the interactional metadiscourse that takes place in the original text. The contact tools identified were then grouped based on the structure outlined by Hyland (2005) according to their categories, which are hedges, boosters, attitude markers, and communication markers. As stated by Corbin and Strauss (2008), paper review from online sources helps to obtain understanding and build analytical information from the data in which researchers needed to know the roles of the metadiscourse components used in the data.

\subsection{Sample}

The sample is taken from a news article from the writing of Bob Spires, the Assistant Professor of Education, the University of Richmond in a news blog called 'How other countries reopened schools during the pandemic' - and what the US can learn from them. 


\subsection{Instrument}

Table 3: Coding for metadiscourse markers

\begin{tabular}{|l|l|l|l|}
\hline Main & Sub-Category & Code & Function \\
\hline \multirow{5}{*}{$\begin{array}{l}\text { Interactional } \\
\text { Resources }\end{array}$} & Hedges & In-Tn $(\mathrm{H})$ & $\begin{array}{l}\text { Withhold the writer's full commitment to } \\
\text { the statement }\end{array}$ \\
\cline { 2 - 4 } & Emphatics & In-Tn $(\mathrm{E}))$ & $\begin{array}{l}\text { Emphasis force of writer's certainty in } \\
\text { message }\end{array}$ \\
\cline { 2 - 4 } & $\begin{array}{l}\text { Attitude } \\
\text { Markers }\end{array}$ & $\begin{array}{l}\text { In-Tn }(\mathrm{AM}) \\
\text { Express writer's attitude to propositional } \\
\text { content }\end{array}$ \\
\cline { 2 - 4 } & $\begin{array}{l}\text { Rational } \\
\text { Markers }\end{array}$ & $\begin{array}{l}\text { In-Tn } \\
(\text { EgM) }\end{array}$ & $\begin{array}{l}\text { Explicitly refer in building relationship } \\
\text { with the reader }\end{array}$ \\
\cline { 2 - 4 } & Personal Markers & In-Tn (SM) & Explicit references to the author(s) \\
\hline
\end{tabular}

Source: Hyland's (2005).

It was broken down into groups and coded like Table 1.

\subsection{Method Data Collection}

3.4.1 Where is the data found?

The data was found through an online platform in the University of Richmond's sparing websites called theconversation.com. The news articles were written on July 22, 2020.

\subsubsection{How do you collect it?}

The researcher went to the web to look and study the impact of Covid-19 in education when they found the writer's write up about the comparison of how other countries reopened school during the pandemic. After thorough reading through the text, researchers decided that they wanted to review how the writer felt about the issue through his writing.

\subsection{Method of Data Analysis}

\subsubsection{Reliability}

The reliability of the study is achieved when two researchers from the same group reviewed and coded the news article using the indication from Hyland's (2005) implication of metadiscourse markers. The coding was done separately and then compared to discuss to reach mutual understanding while producing the data marking results.

\subsection{Data collection}

The data analysis was done by replicating the study done by Hyland (2005). The English text written by Spires (2020) on the web about the impact of COVID 19 on educational institutions of few countries was marked using the metadiscourse marker by Hyland (2005). The metadiscourse markers were marked and tagged using different colors and codes. The categorized metadiscourse marker was then tabulate based on the categories using the taxonomy by Hyland (2005). After that, the number of tagged metadiscourse markers were counted and categorized. 


\subsubsection{Data analysis}

The data were analysed quantitatively, using frequency and percentage, as well as qualitatively. The divisions that emerge from each analysis are then separately presented, following each research question.

\section{Discussion}

\subsection{Introduction}

This section presents the findings and analysis, organized in the context of the sequence of research questions.

1) How are interactional metadiscourse resources on news articles transcribed in terms of hedges and boosters?

2) How are interactional metadiscourse resources on news articles transcribed in terms of attitude-markers and engagement-markers?

3) How are interactional metadiscourse resources on news articles transcribed in terms of personal markers?

4) How does the frequency of usage differ across all metadiscourse markers?

\subsection{Interactional Resource}

RQ 1: How are interactional metadiscourse resources on news articles transcribed in terms of hedges and boosters?

\subsubsection{Qualitative Findings}

\section{a. Hedges}

[1] "As American school officials debate when it will be safe for schoolchildren to return to classrooms, looking abroad may offer insights" [Line 3]

[2] “Too much, too soon" [Line 12]

[3] "...the disease may have affected..." [Line 46-47]

Based on the excerpts included above, the bolded words are classified as hedges as it portrays the trait and characteristic of hedges. Some traits of hedges are to refuse to commit, to show uncertainty, to be open for alternative opinions, or to be more subtle in giving viewpoints (Hu \& Cao, 2011). Excerpts 1 and 3 show the sentences contain hedges because the author is trying to subtly express her insight. In excerpt 2, the author used hedges as he is voicing the need for further study in the related field. According to Reza 2010, hedges is critical strategies in establishing the need for a study in that, admittedly, research areas are for the most part uncharted lands that require cautious handling. 


\section{b. Boosters}

[1] “...reopening in Israel that, many experts say, came too soon and..." [Line 22-23]

[2] “...officials in Stockholm have admitted they don't know..." [Line 46]

[3] "... according to a joint study from Sweden's Upsala University..." [line 49]

[4] "A survey from Save the Children found that Japanese school..." [line 59]

[5] "Analysts credit Uruguay's well-organized and efficient.." [line 59]

Based on the excerpts included above, the bolded words are classified as hedges as it portrays the trait and characteristic of boosters. The use of hedges enables the writers to express a perspective on their statements, to present unproven claims with caution and to enter to a dialogue with their audience, while the use of boosters helps him/her to close down alternatives and to show a high degree of certainty (Hyland, 2005). In excerpts 1,2 and 3 the author used the boosters in the sentences to show that he was certain in stating the sentence based on fact from a study. Meyer (1997) view the term 'boosters' as those lexical items by means of which the writer can show strong confidence for a claim. Excerpts 4 and 5 on the other hand shows that the writer is proving his point by using the claim made proven with factual count.

\section{RQ 2: How are interactional metadiscourse resources on news articles transcribed in terms of attitude-markers and engagement-markers?}

\section{c. Attitude Markers}

[1] "Here's what I found" [Line 11]

[2] "Only one young Swedish child is believed to have died..." [Line 44-45]

[3] "However, officials in Stockholm have admitted they don't..." [Line 46]

[4] "Japan: So far, so good" [Line 51]

[5] "There is no perfect way to reopen schools during a pandemic" [Line 78]

[6] "But the policies and practices.." [Line 80]

The above highlighted words are considered as attitude marker because it expresses writers' attitude to proposition. The purpose of boosters is to help express the writer's stand and opinion about the topic they write Ali \& Azirah (2019). In excerpts 1 to 4, the writer is trying to express his stand towards the topic. Excerpts 5 and 6 on the other hand shows the writer's opposition towards the issue which is a part of his believe towards the topic.

\section{d. Engagement Markers}

[1] "But shortly after schools..," [Line 16]

[2] "But schools were only part of a broader..." [Line 22]

[3] "University of Virginia. Of those, slightly more.." [Line 50]

[4] "Most countries have national education systems.." [Line 91] 
According to the excerpts given above, the bolded word is counted as engagement marker because it suits the purpose as mentioned by Sahragard \& Yazdanpanahi (2017), to help the authors to use appropriate words to oppose, negotiate, and connect with the readers.

\section{RQ 3: How are interactional metadiscourse resources on news articles transcribed in terms of personal markers?}

\section{e. Personal Markers}

[1] "I am a scholar of comparative international education." [line 7]

[2] "For this article, I examined..." [Line 7]

[3] "Here's what I found..." [Line 8]

There is minimal usage of personal marker in this article as the writer is reporting the COVID-19 effect in education at few countries. However, the two mentioned excerpts explained the reference of the author which in this case uses I as the personal pronounce.

\subsubsection{Quantitative Findings}

Research Question 4: How do the frequency of use differ across all metadiscourse markers?

Table 4: Frequency of usage for interactional metadiscourse

\begin{tabular}{|l|l|c|c|c|}
\hline Main Category & Sub-category & Code & Frequency & Percentage (100\%) \\
\hline \multirow{4}{*}{$\begin{array}{l}\text { Interactional } \\
\text { Resources }\end{array}$} & Hedges & In-Tn (H) & 3 & 13.63 \\
\cline { 2 - 5 } & Boosters & In-Tn (B) & 5 & 22.73 \\
\cline { 2 - 5 } & Attitude Markers & In-Tn (AM) & 7 & 31.81 \\
\cline { 2 - 5 } & Rational Markers & In-Tn (EgM) & 4 & 18.19 \\
\cline { 2 - 5 } & Personal Markers & In-Tn (SM) & 3 & 13.63 \\
\hline Sub-Total Interactional & & & 22 & 100 \\
\hline
\end{tabular}

\subsubsection{Quantitative Findings}

The table 4 above shows the number of frequencies and percentages of the interactional resources analyzed from an article written by Assistant Professor of Education, University of Richmond.

The article is comparing how other countries reopened schools during the pandemic of COVID 19 and what the US can learn from them. The table above shows that attitude marker is the highest content of interactional resources sub-category compared to others with the percentage of $31.81 \%$. The second highest interactional resources are boosters $22.73 \%$. The usage was then followed by rational markers with $18.19 \%$. Hedges and personal markers on the other hand scored the same percentage of usage which is $13.63 \%$. In conclusion, the article has used all the interpersonal model of metadiscourse by Hyland (2005). 


\section{Conclusion}

\subsection{Introduction}

In this section, the finding of the study is discussed.

\subsubsection{Summary of Findings}

The finding of this research concluded that metadiscourse study is vital in emphasizing the writer's belief towards their writing. It also promotes appeal towards reader and suggested how the reader should feel upon certain topic. If a proper use of metadiscourse markers is used in the writing, a connection and trust between writer and reading can be built. The research has also shows that this article uses personal markers and hedges the least. This is due to the article is collected from news article where the writers are writing facts rather than appealing or writing with emotions. Finally, the results also showed that attitude markers were the most used in interactional metadiscourse study in this news article.

\subsection{Implications/Recommendations}

This research will guide future researcher to understand and study well on metadiscourse markers in text. It is recommended for future researcher to use the metadiscourse markers to investigate texts in bigger point of view to get wider understanding pertaining this linguistic marker.

\subsection{Suggestions for Future Research}

It is suggested for future researcher to conduct the study is larger sample size . Other than that, future researcher may conduct the study not only in interactional but also in interactive point of metadiscourse marker. This research is limited to investigating in online new article from the perspective of the interactional resources of metadiscourse only. Because text limitation from the original source, interactive point of view was not covered in this research. There is also tremendous scope for future studies in this field to investigate both tools of metadiscourse not only from online news articles but from offline scope as well in order to achieve a better understanding of the use of metadiscourse taxonomy.

\section{Conflict of Interest Statement}

The authors declare no conflicts of interests.

\section{About the Author(s)}

Nur Azyan Aszeli and Daniel Amer Jamil are Postgraduate students of Master of Professional Communication at Akademi Pengajian Bahasa, Universiti Teknologi MARA, Malaysa.

Noor Hanim Rahmat is an associate professor teaching at Akademi Pengajian Bahasa, Universiti Teknologi MARA, Malaysa. Her areas of expertise include TESL methodology, language skills educational psychology and academic reading and writing. 


\section{References}

Abdullah, N. A., Rahmat, N. H., \& Zawawi, F. Z. (2020). Interactional Discourse Analysis of Malaysian and South Korean Newspaper Articles on Online Learning During Covid-19. Retrieved from https://oapub.org/lit/index.php/EJALS/article/view/186

Afshar, A., M., and Foad, S., E. (2016). Realization of Attitude and Engagement Markers in Students' Presentation. International Journal of Applied Linguistics E English Literature, 7377.

Al-Ghoweri, H., A., and Al Kayed, M., M. (2019). A Comparative Study of Hedges and Boosters in English and Jordanian Arabic: Economic Newspaper Articles as a Case Study. Theory and Practice in Language Studies, 52-59.

Ali, S., A., and Azirah, H. (2019). The Impact of Attitude Markers on Enhancing Evaluation in the Review Article Genre . Journal of Language Studies, 153-173.

Anuarsham, A., Rahmat, N., \& Khamsah, M. (2020). Metadiscourse Analysis of an Online Entertainment Article. Retrieved November 26, 2020, from https://www.oapub.org/lit/index.php/EJALS/article/view/187

Corbin, J., \& Strauss, A. (2008). Basics of qualitative research: Techniques and procedures for developing grounded theory (3rd ed.). Thousand Oaks, CA: Sage.

Demir, C. (2017). Competence in Lexical Boosters and Nativeness in Academic Writing of English: The Possible Relation. Journal of Language and Linguistic Studies, 593-614.

Hu, G., and Cao, F. (2011). Hedging and Boosting in Abstracts of Applied linguistics Articles: A Comparative Study of English- and Chinese-Medium Journals. Journal of Pragmatics, 2795-2809.

Ho, V., \& Li, C. (2018, February 08). The use of metadiscourse and persuasion: An analysis of first year university students' timed argumentative essays. Retrieved November 26, 2020, from https://www.sciencedirect.com/science/article/pii/S1475158518300511

Hyland, K. (2005). Metadiscourse: Exploring Interaction in Writing . London: Continuum.

Hyland, K. (2015). Metadiscourse. In K. Tracy (Ed.), The International Encyclopedia of Language and Social Interaction, 1-11. John Wiley \& Sons, Inc.

Kadir, N., Rahmat, N., Wahid, H., \& Dzuradeen, N. (1970, January 01). Positive Side of Covid19? A Metadiscourse Analysis of a Personal Blog: Semantic Scholar. Retrieved November 26, 2020, from https://www.semanticscholar.org/paper/POSITIVE-SIDE-OF-COVID-19A-METADISCOURSE-ANALYSIS-Kadir-

Rahmat/f9f5d514fe959f4662b8defa7bff92302a05bb00

Karakaya, S., \& Glazier, R. A. (2019). Media, information, and political participation: The importance of online news sources in the absence of a free press. Retrieved November 26, 2020, from https://www.tandfonline.com/doi/abs/10.1080/19331681.2019.1645784

Lee, J., \& Deakin, L. (2016, July 14). Interactions in L1 and L2 undergraduate student writing: Interactional metadiscourse in successful and less-successful argumentative essays. Retrieved November 26, 2020, from https://www.sciencedirect.com/science/article/pii/S1060374316300315 
Qadir, A., and Shakir, M. (2015). Attitude Markers in the Writing of EFL Learners: A PragmaStylistic Study. IRAQI Academic Scientific Journals, 30-44.

Sahragard, R., and Yazdanpanahi, S. (2017). English Engagement Markers: A Comparison of Humanities and Science Journal Articles. Language Art, 111-130.

Sardabi, N., \& Afghari, A. (2015). Gender differences in the use of intensifiers. Journal of Applied Linguistics and Language Research, 2(7), 203-213. Retrieved from http://jallr.com/index.php/IALLR/article/view/174

Spires, B. (2020, June 22). How other countries reopened schools during the pandemic - and what the US can learn from them. The Conversation.

https://theconversation.com/how-other-countries-reopened-schools-during-the-pandemic-andwhat-the-us-can-learn-from-them-14270

Tanikawa, M. (2017). (PDF) What is news? What is the newspaper? The physical ... Retrieved November 26, 2020, from

https://www.researchgate.net/publication/327176409 What is news What is the news paper The physical functional and stylistic transformation of print newspapers 198 8-2013 International Journal of Communication11 3519-3540

Wahid, H. S. A., Rahmat, N. H., Dzuradeen, N. S., and Kadir, N. A. (2020). Are Students Engaging in Online Classrooms. European Journal of Education Studies, Vol 7(12), pp 202-222. Retrieved from https://oapub.org/edu/index.php/ejes/article/view/3408 
Nur Azyan Aszeli, Daniel Amer Jamil, Noor Hanim Rahmat to their work. Under the terms of this license, no permission is required from the author(s) or publisher for members of the community to copy, distribute, transmit or adapt the article content, providing a proper, prominent and unambiguous attribution to the authors in a manner that makes clear that the materials are being reused under permission of a Creative Commons License. Views, opinions and conclusions expressed in this research article are views, opinions and conclusions of the author(s). and European Journal of Literature, Language and Linguistics Studies shall not be responsible or answerable for any loss, damage or liability caused in relation to/arising out of conflicts of interest, copyright violations and inappropriate or inaccurate use of any kind content related or integrated into the research work. All the published works are meeting the Open Access Publishing requirements and can be freely accessed, shared, modified, distributed and used in educational, commercial and non-commercial purposes under a Creative Commons Attribution 4.0 International License (CC BY 4.0). 